\title{
Stable isotope geochemistry and petrography of the Qorveh-Takab travertines in northwest Iran
}

\author{
Reihaneh ROSHANAK ${ }^{1 *}$, Farid MOORE ${ }^{2)}$, Alireza ZARASVANDI ${ }^{1)}$, Behnam KESHAVARZ(2) \& Reinhard GRATZER ${ }^{3)}$ \\ 1) Department of Geology, Faculty of Sciences, Shahid Chamran University, Ahvaz 87234, Iran; \\ 2) Department of Earth Sciences, College of Sciences, Shiraz University, Shiraz 71454, Iran; \\ 3) Department of Applied Geosciences and Geophysics, Montanuniversitaet Leoben, Peter-Tunner-Strasse 5, 8700 Leoben, Austria; \\ *) Corresponding author, r-roshanak@phdstu.scu.ac.ir
}

\section{탕면}

KEYWORDS

\begin{abstract}
The Qorveh-Takab travertines, which are connected to thermal springs, are situated in the northwest of the SanandajSirjan metamorphic zone in Iran. In this study, the travertines were investigated applying petrography, mineralogy and isotope geochemistry. Oxygen and carbon isotope geochemistry, petrography, scanning electron microscopy (SEM) and X-ray powder diffraction (XRD) analysis were used to determine the source of the $\mathrm{CO}_{2}$ and the lithofacies and to classify the travertines. Isotope studies, morphological and mineralogical observations and distribution of travertines revealed that the travertines of the Qorveh-Takab could be of thermal water origin and, therefore, belong to the thermogene travertine category. These travertines are usually massive with mound-type morphology and are essentially found in regions with recent volcanic or high tectonic activity.

The measured $\delta^{13} \mathrm{C}$ values of the travertines indicate that the $\delta^{13} \mathrm{C}$ of the $\mathrm{CO}_{2}$ released from the water during travertine deposition, while the source of the $\mathrm{CO}_{2}$ in the water springs seems to have been of crustal magmatic affinity. These travertines are divided into two lithofacies: (1) crystalline crust travertine and (2) pebbly (phytoclastic travertine with pebble-size extraclasts) travertine. $\delta^{18} \mathrm{O}$ and $\delta^{13} \mathrm{C}$ values of travertines are -0.6 to -11.9 (\%oVPDB) and +6.08 to +9.84 $(\% \circ \mathrm{VPDB})$, respectively. A probable reason for the heavy carbon isotope content observed in these deposits is the presence of algae microorganisms, which was verified by SEM images. Fissure ridges, fluvial crusts with oncoids, and mound morphological features are observed in the study area. Based on the petrographic and SEM criteria, Qorveh-Takab travertines are classified into four groups: (1) compacted, (2) laminated, (3) iron-rich spring deposit and (4) aragonite-bearing travertines. Stable isotope compositions of Turkish travertines are largely similar to the travertines in the study area.
\end{abstract}

\section{Introduction}

Travertines are limestones precipitated from hot waters, which are rich in bicarbonate and calcium and appear at caves, streams, springs and lakes (e.g., Viles and Goudie, 1990; Pentecost and Viles, 1994; Guo and Riding, 1998). Travertine and tufa, despite their identical chemical composition and similar characteristics, are different in their lithofacies and depositional environments. Tufa has a higher porosity and woody texture and is generally a cool freshwater deposit. Conversely, travertine is commonly deposited in warm water and is stronger lithified (Atabey, 2002; Pentecost, 2005). Most known travertine deposits are recent or Quaternary (Sierralta et al., 2010; Kalender et al., 2015). Travertines are widespread all over the world, e.g., in Italy, Spain, Turkey and China (Prado-Pérez et al., 2013; Gandin and Capezzuoli, 2014; Ozkul et al., 2014; Wang et al., 2014).

Carbon dioxide outgassing leads to the rapid deposition of travertines from mineral saturation water and also increase their pH (Pentecost, 1995). The internal structure of travertines often shows lamination with less than $1 \mathrm{~mm}$ intervals between the laminae (lamination texture in an aragonitic travertine is created under several flow states). The origins of the lamination depend on many factors such as spring activity, underlying topography, chemical composition of travertine-depositing waters, biological processes and surface water (Ozkul et al., 2002). Calcareous spring deposits are formed by calcite and aragonite. The relatively little mineralogical diversity is accompanied by an immense variety of facies and microfacies (Jones and Renaut, 2010). Precipitation and facies of travertines often depend on biological processes of certain microorganisms, such as algae and bacteria (Casanova, 1986; Rahmani et al., 2012).

Recently, there has been a great number of studies on geochemistry, morphological types, macro- and micro-organic components, stable isotope variations and dating of travertines (i.e. Selim and Yanik, 2009; Prado-Pérez et al., 2013; Gandin and Capezzuoli, 2014; Kalender et al., 2015). Based on the origin of carbon dioxide, travertines can be divided into two groups (Pentecost and Viles, 1994; Pentecost, 2005). (1) The first group is 'meteogene travertine', which refers to deposits organized in $\mathrm{CaCO}_{3}$-rich water; the $\mathrm{CO}_{2}$ content of such travertines comes from the groundwater and soil. (2) The second group is thermogene travertine, which results from thermal processes, including magmatic degassing or decarbonation of limestone during thermometamorphic processes (Pentecost and Viles 1994; Minissale et al. 2002, 
Viles and Pentocost, 2007). Thermogene travertines are characterized by (1) negative values of $\delta^{18} \mathrm{O}$, (2) positive values of $\delta^{13} \mathrm{C}$ and (3) a covariation tendency downstream with enhancement in both $\delta^{13} \mathrm{C}$ and $\delta^{18} \mathrm{O}$ values (Chafetz and Lawrence, 1994). Pentecost (2005) defined eight morphological groups of travertines: (1) mound, (2) fissure ridge, (3) paludal, (4) cascade (including dripstone), (5) dam, (6) fluvial crust, (7) cemented rudite/clast and (8) lacustrine crust and reef.

Major travertine deposits are exposed in the northwest (NW) of Iran within an NW-southeast (SE) trend (Fig. 1). This area embraces two geological zones, the Urumieh-Dokhtar volcano-plutonic zone and Sanandaj-Sirjan metamorphic zone, which include a large number of active hot springs.

This study focuses on petrography and oxygen and carbon isotope geochemistry of the Qorveh-Takab travertines from the Sanandaj-Sirjan metamorphic zone to identify geochemically the source of the $\mathrm{CO}_{2}$ and to characterize the lithofacies of the travertines.

\section{Regional geological setting}

The Qorveh-Takab area is situated in the west of Iran country and belongs to two provinces: West Azerbaijan and Kurdistan (Fig. 1). The study area was around the Takab city in the West Azerbaijan province and at Qorveh and Bijar cities in the Kurdistan province. This area is distinguished by cold, snowy winters and a Mediterranean climate, with a mean annual rainfall of $480 \mathrm{~mm}$ (for the term 1993 to 2003 at Bijar, Qorveh and Takab stations). The average annual temperature is about $6.13^{\circ} \mathrm{C}$. Covering a surface area of nearly $7483 \mathrm{~km}^{2}$, the study area belongs to the Sanandaj-Sirjan structural zone (GSI, 1999). Igneous, sedimentary, and metamorphic rocks are found in the area. Metamorphic Cretaceous sandy shale and slates of dark green colours are the oldest rocks. The younger ones are the travertines and alluvial terraces and fans, as well as quaternary andesitic to alkali basalts. The composition of the volcanic rocks is mafic (alkali basalt, hawaiite, mugearite) (Karimi Nezhad et al., 2010).

The widespread travertine deposits covering the volcanic rocks demonstrate the waning phases of tertiaryquaternary volcanic activities (Boni et al., 2007). Extending from NW to SE, the travertine-depositing springs found in the study area are related to the basic volcanoes. Probably, the active hydrothermal systems of the fractures originated from fluids of deep-seated origins. In addition, the hydrothermal fluid circulation may have resulted from the numerous springs caused by deep fractures in the deposits (Keshavarzi et al., 2011). Samples of travertines studied in this paper belong to recent thermal springs and were often collected near the active springs.

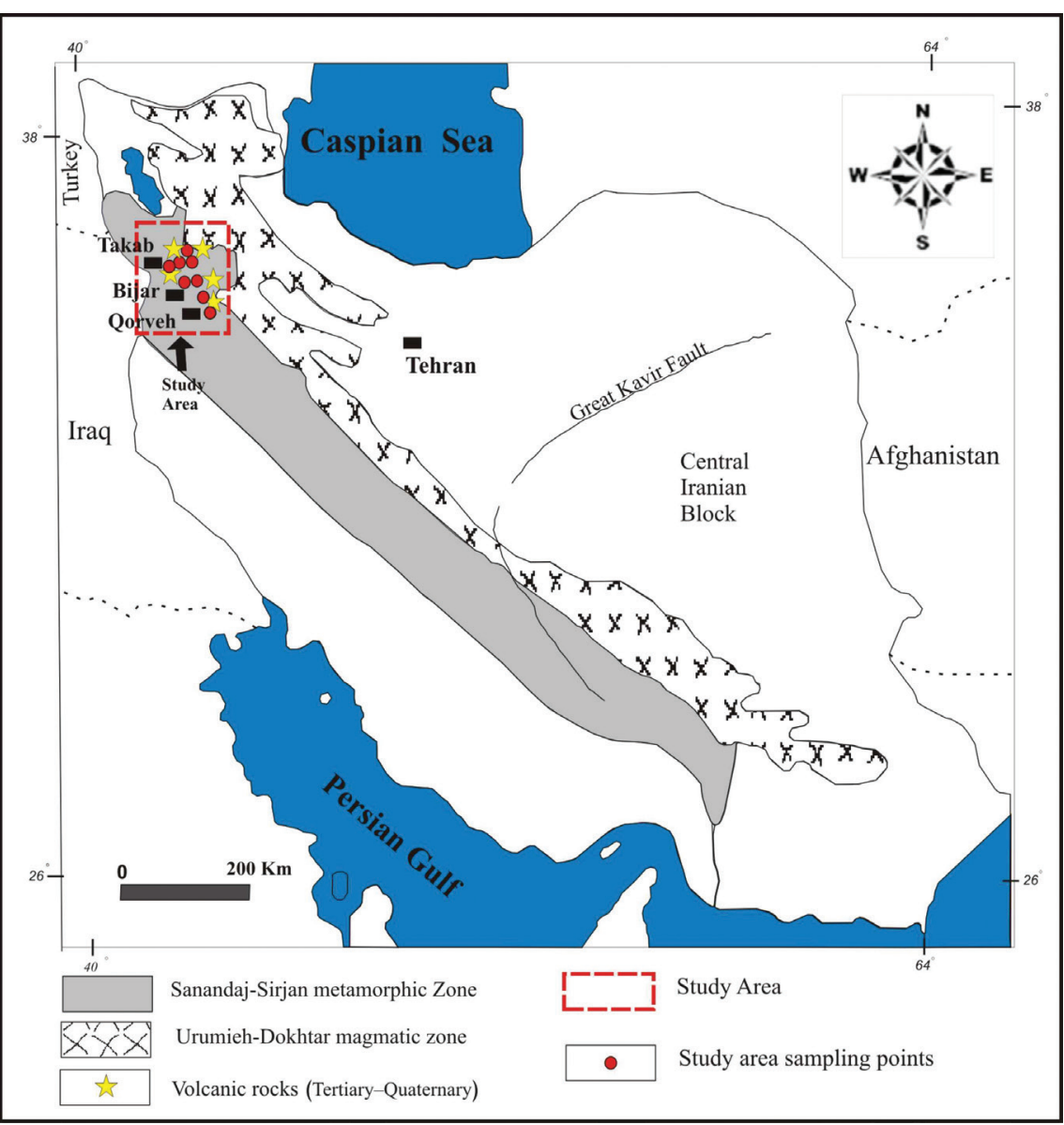

Figure 1. Geographical and structural zones of Iran and the study area.

\section{Material and methods}

The travertine samples were taken from three regions (Qorveh, Bijar and Takab). Fifty-five samples of fresh travertine were collected in order to determine their mineralogical properties and fabric by using thin sections of rock specimens and a standard petrographic microscope. Twelve samples were chosen for scanning electron microscopy (SEM). Photographs were taken by using the Hitachi S-4160 scanning electron microscope of the University of Shiraz. Also, ten samples were analysed by X-ray powder diffraction (XRD) with $\mathrm{Cu} \mathrm{K} \alpha 1$ radiation at the Mineralogical Laboratory of the Geological Survey of NW Iran. In this laboratory, samples were analyzed using the X-ray diffractometer 'Siemens D5000'. Eight samples were used for oxygen and carbon isotopic analyses. Carbon and oxygen isotopic analyses were carried out with the help of powdered samples, using the phosphoric acid method of Burman et al. (2005). About $1 \mathrm{~g}$ of powdered sample was washed with $100 \%$ phosphoric acid at $70^{\circ} \mathrm{C}$ for $3 \mathrm{~min}$ in a Thermo 
Fisher GasBench device connected to a Thermo Fisher Delta $V$ mass spectrometer at the ETH Stable Isotope Laboratory (Zurich, Switzerland). The reproducibility of the measurements-based on repeated standardswas $\pm 0.05 \%$ o for $\delta^{13} \mathrm{C}$ and $\pm 0.06 \%$ or for $\delta^{18} \mathrm{O}$. Results were corrected using the NBS 19 standard $\left(\delta^{13} \mathrm{C}=1.95\right.$ and $\left.\delta^{18} \mathrm{O}=-2.2 \% 0\right)$ and NBS 18 standard $\left(\delta^{13} \mathrm{C}=-5.01\right.$ and $\delta^{18} \mathrm{O}=-23.01 \%$ ). Values obtained were expressed in $\delta$ notation in parts per thousand (\%o) and referred to the Vienna Pee Dee Belemnite (VPDB) standard.

\section{Results}

\subsection{Morphology}

Three types of travertines had been observed in the study area (Qorveh, Bijar and Takab areas): (1) mound, (2) fissure ridge and (3) fluvial crust. Most of the travertine deposits in the study area can be classified as a spring mound, which displays a close resemblance to the famous Pamukkale travertine deposits at Denizli, Turkey, and Mammoth Hot Springs in Wyoming, USA (Chafetz and Folk, 1984; Ozkul et al., 2002; Inskeep and McDermott, 2005). Qorveh-Takab road travertines display a range of morphological structures, textures and facies.

\subsubsection{Mounds}

These travertine domes of a height of less than $1 \mathrm{~m}$ to more than $100 \mathrm{~m}$ surround a spring orifice and comprise mounds. The solid geometries of most of the mounds are determined by the orifice, including circular and pipe-like or linear and sheet-like shapes at their hydrostatic heads. Subdivision of the mounds can be done based on their positions and hydrology (Pentecost, 2005). Most travertines in the study area display exposed mound morphology (Fig. 2A). Most of the travertine mounds observed in West Azerbaijan and Kurdistan provinces are between $3 \mathrm{~m}$ and $20 \mathrm{~m}$ high. In the field study areas, there were very large mounds such as 'Zendan Soleyman' near Takab, West Azerbaijan Province. This hollow cone was about $107 \mathrm{~m}$ high and $65 \mathrm{~m}$ wide.

\subsubsection{Fissure ridges}

Elongated wedge-like structures called fissure ridges have a height of 1-15 $\mathrm{m}$ and a length exceeding $0.5 \mathrm{~km}$. These ridges make fractures like joints or faults, along which travertines are built up around the spring orifices (Pentecost, 2005). Two instances of inactive fissure-ridge travertines are exposed in the studied area, at Baba Gorgor village in the Qorveh area (Fig. 2B). Fissure-ridge
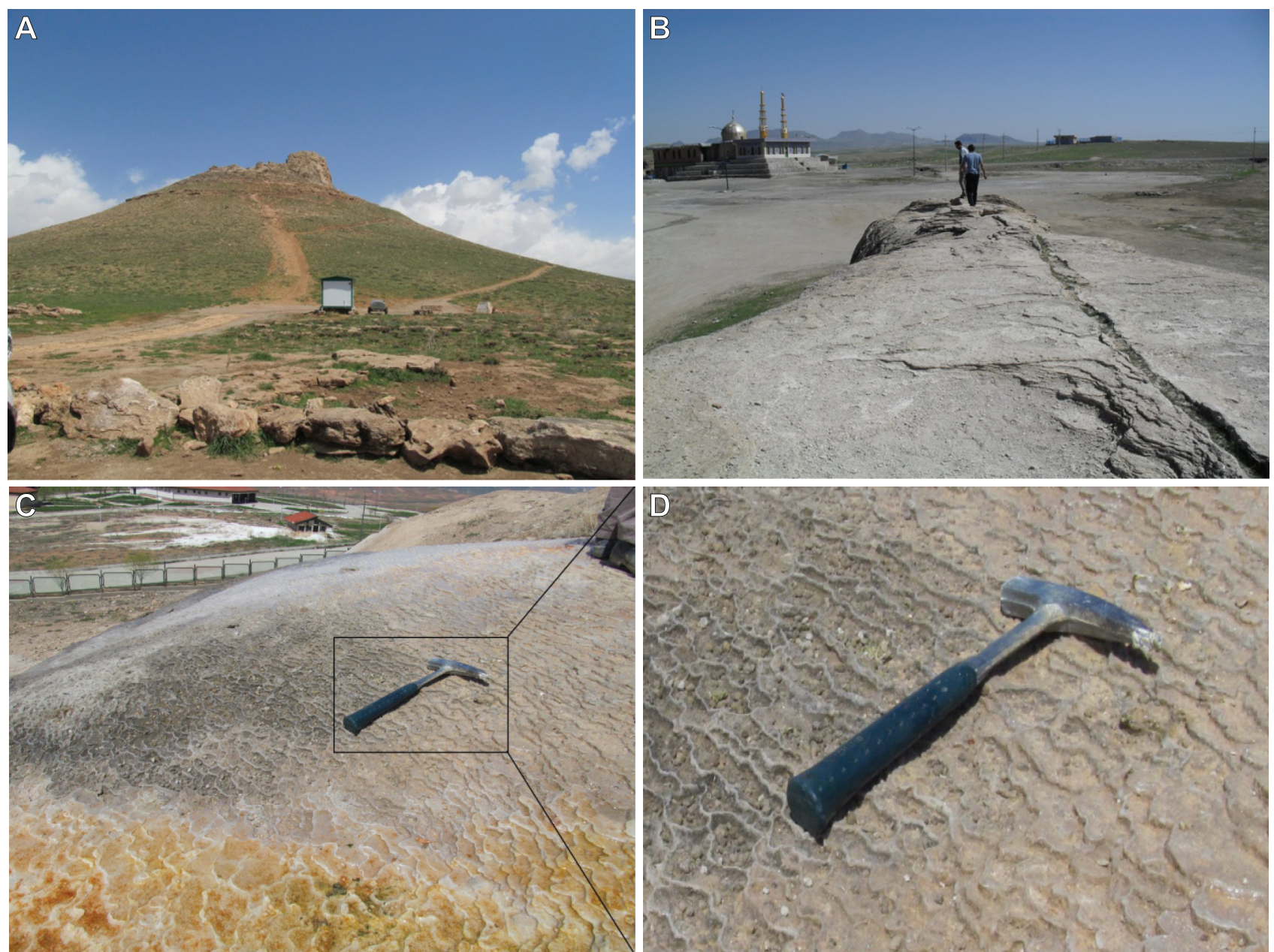

Figure 2. Morphological features of studied travertine formations: A) mounds (Zendan Soleyman mound located $40 \mathrm{~km}$ northeast of Takab), B) fissure ridges (Baba Gorgor area located in northeast Qorveh) and C,D) fluvial crusts (Ahmadabad area in west Azerbaijan province). 
travertines comprise a longitudinal hill (similar to a dragon from the top view) with a length of $300 \mathrm{~m}$, width of $7 \mathrm{~m}$ and height of $5 \mathrm{~m}$ in the Baba Gorgor area. The typical structures of these travertines are made of a fissure at the centre of the ridge with hard and compact crystal crusts laminated parallel to the fissure.

\subsubsection{Fluvial crusts}

Frequently associated with oncoids, fluvial crusts are formed by superficial deposits in running water but not directly by cascades, while developing various smooth and sheet-like or nodular and coralloid substrata (Pentecost, 2005). The morphology of fluvial crusts in the study area is exposed in Takab travertines (Fig. 2C, D).

\subsection{Lithofacies}

In the Qorveh-Takab area, two main travertine lithofacies fields are readily recognizable: (1) pebbly (phytoclastic travertine with pebble-size extraclasts) travertine and (2) crystalline crust travertine. The variations in stable isotope values (Fig. 3) in the lithofacies deposited within the different environments of smooth or terraced slopes, under the various conditions such as water temperature, flow velocity and distance from spring, surface area and biological effects, are possible (Ozkul et al., 2002).

\subsubsection{Pebbly travertine lithofacies}

Some travertines contain sparse rounded pebbles of limestone, marble, chert, radiolarite and serpentinite (Ozkul, 2002). These lithofacies are called 'phytoclastic' in Italy and are also associated with rock fragments of

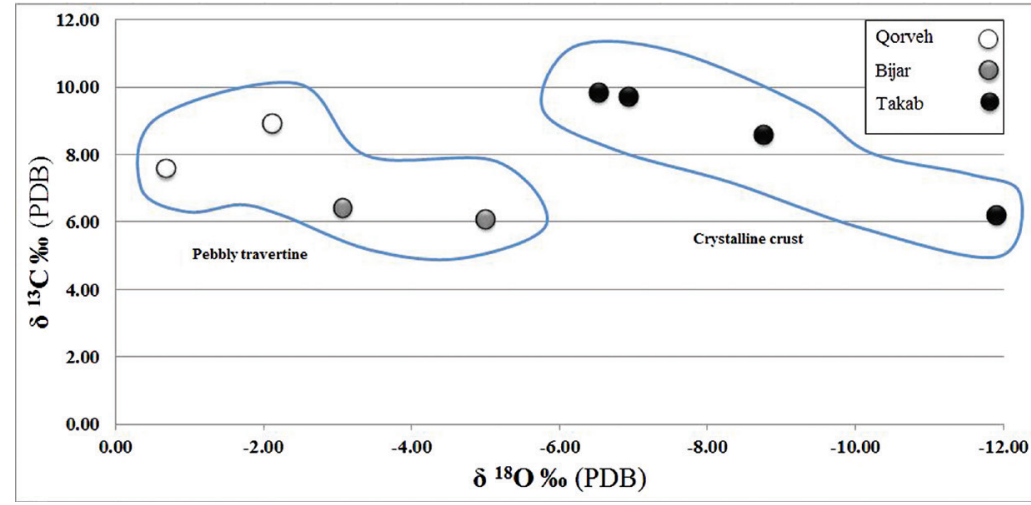

Figure 3. $\delta^{18} \mathrm{O} \%$ VPDB vs. $\delta^{13} \mathrm{C} \%$ VPDB values of the Qorveh, Bijar and Takab travertines.
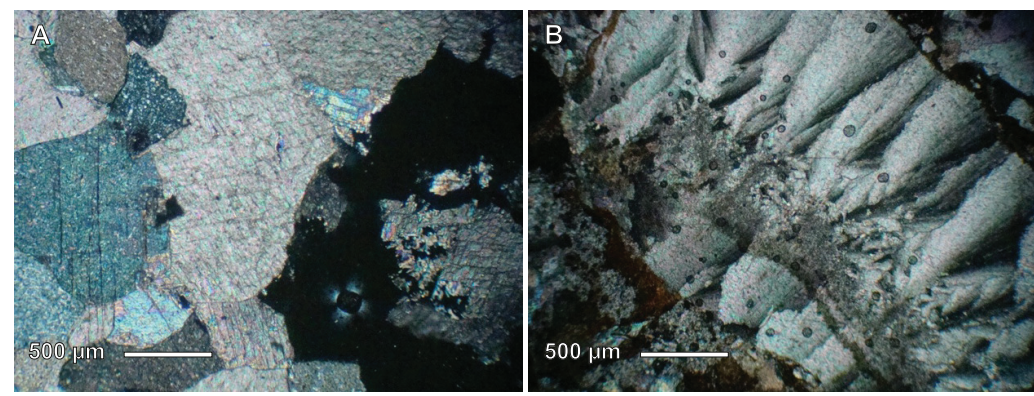

Figure 4. Photomicrograph of A) pebbly travertine lithofacies (Qorveh area) and B) crystalline crust travertine lithofacies in the Bijar area. non-travertine origin (phytoclastic travertine with pebble-size extraclasts) (D'Argenio and Ferreri, 1992). Some travertines investigated in the Qorveh region show pebbly travertine lithofacies (Fig. 4A). Calcite and aragonite particles are massively textural and, as a result of the low porosity between crystals, are densely packed.

\subsubsection{Crystalline crust travertine lithofacies}

Crystalline crust travertines commonly form as a result of quick sedimentation from fast-flowing waters on flat slopes, edges and vertical walls of terrace pools, cliff surfaces of waterfall sub-environments and in extensional fissures. Crystalline crusts are commonly compact, light-coloured and fibrous, consisting of elongated calcite feathers growing vertically on the depositional surface (Guo and Riding, 1998; Ozkul, 2002). In Bijar and Takab areas, crystalline crust lithofacies can be observed (Fig. 4B).

\subsection{Petrography}

In the study area, travertines are of different types of textures and compositions. The percentages of calcite and aragonite minerals were determined by quantitative XRD analysis (Table 1). With the investigation of thin sections and $X R D$ results, the travertines studied can be divided into four categories: (1) massive travertines, (2) layered travertines, (3) iron-rich spring deposits and (4) aragonite-bearing travertines.

\subsubsection{Massive travertines}

This group of travertines is not layered and is full of calcite and dolomite crystals embedded in the micritic matrix. Dolomite grain size of about $10 \mu \mathrm{m}$ in the samples and the mosaic with calcite particles and a relatively straight line can be seen (Fig. 5). According to XRD results, this group of travertines has about $98 \%$ calcite (Table 1).

\subsubsection{Layered travertines}

The most prominent feature of this group is dark and light layers of calcite with aragonite. These travertines have a light colour and are without diamond-shaped dolomites, unlike the massive travertines. In this category, iron oxides with stylolite texture are found (Fig. 6). According to XRD results, this group of travertine has more than $90 \%$ calcite (Table 1 ).

\subsubsection{Iron-rich spring deposit}

The main feature of this category of travertine is the presence of iron oxides. These samples are mostly not regularly layered and contain coarse calcite crystals. In addition, iron oxides have stylolite textures (Fig. 7). In SEM pictures of these travertines, particles of crystalline calcite, aragonite and mainly iron oxides with cauliflower texture can be seen (Fig. 8). These travertines have a high content of calcite minerals (Table 1). 
Samples Location Calcite \% Aragonite \% Categories

\begin{tabular}{lllrl}
\hline T-1 & Qorveh & 99.5 & 0.3 & Massive \\
T-3 & Qorveh & 41.8 & 46.8 & Aragonite-bearing \\
T-4 & Bijar & 87.3 & 6.5 & Layered \\
T-6 & Bijar & 83.7 & 0.5 & Iron-rich \\
T-7 & Takab & 30.2 & 47.8 & Aragonite-bearing \\
T-8 & Takab & 98.2 & 0.7 & Layered \\
T-9 & Takab & 98.4 & 0.5 & Massive \\
T-10 & Takab & 68.4 & 30.4 & Aragonite-bearing
\end{tabular}

Table 1: XRD results of Qorveh, Bijar and Takab travertines.

\subsubsection{Aragonite-bearing travertines}

Aragonite is an unstable polymorph of carbonate and is usually deposited in the aqueous environment by biological or physical agents under suitable conditions of $\mathrm{pH}$ and pressure. Aragonite usually forms when the temperature increases and $\mathrm{pH}$ is between 8 and 9 .

The crystallization system of aragonite is orthorhombic, and most of the crystals are observed as needles or are of oblong shape, though cauliflower textures and flaky crystals are also seen. Our aragonite-bearing travertine samples have only a few calcite and dolomite minerals. Aragonite crystals often have cluster textures (Fig. 9). According to XRD results, this group of travertines has only about $50 \%$ calcite (Table 1 ).

\subsection{Stable isotope geochemistry}

The carbon and oxygen contents in travertine samples from the Qorveh, Bijar and Takab areas were determined to understand the source of the $\mathrm{CO}_{2}$ that was dissolved in the parent waters of the travertine. The isotope values (Fig. 3; Table 2) are presented in the conventional delta notation with respect to VPDB.

$\delta^{18} \mathrm{O}$ values range between -0.68 and $-11.91 \%$ o (with average of $-5.6 \%$ ), and $\delta^{13} \mathrm{C}$ values are between +6.08 and $+9.84 \%$ o (with an average value of $+7.9 \%$ ). The $\delta^{18} \mathrm{O}$ values generally have a wide range due to variations in water temperature and composition, carbon concentration and ionic species $\left(\mathrm{H}_{2} \mathrm{CO}_{3}, \mathrm{HCO}^{-3}, \mathrm{CO}^{-2}\right)$ controlled by $\mathrm{pH}$ changes (Kele et al., 2008). Usually, regional deep water has $\delta^{18} \mathrm{O}$ between $-5 \%$ and $-8 \%$ o (Hoefs, 2004). The average value of $\delta^{18} \mathrm{O}$ in the QorvehTakab road data is $-5.6 \%$, which falls in this range. According to Pentecost (2005), meteogene travertines' carbon isotope composition averages around $-10 \%$, but $\delta^{13} \mathrm{C}$ values of thermogene travertines (typically $-3 \%$ to $+8 \%$ ) are generally heavier than those of meteogene travertines. Thermogene deposits have a more localized repartition than meteogene deposits and are usually associated with volcanic rocks or tectonic activities (Pentecost, 2005). The average value of $\delta^{13} \mathrm{C}$ in the study area is $+7.9 \%$, and this falls in the range of thermogene travertines $(-3 \%$ o to $+8 \%$ ) .
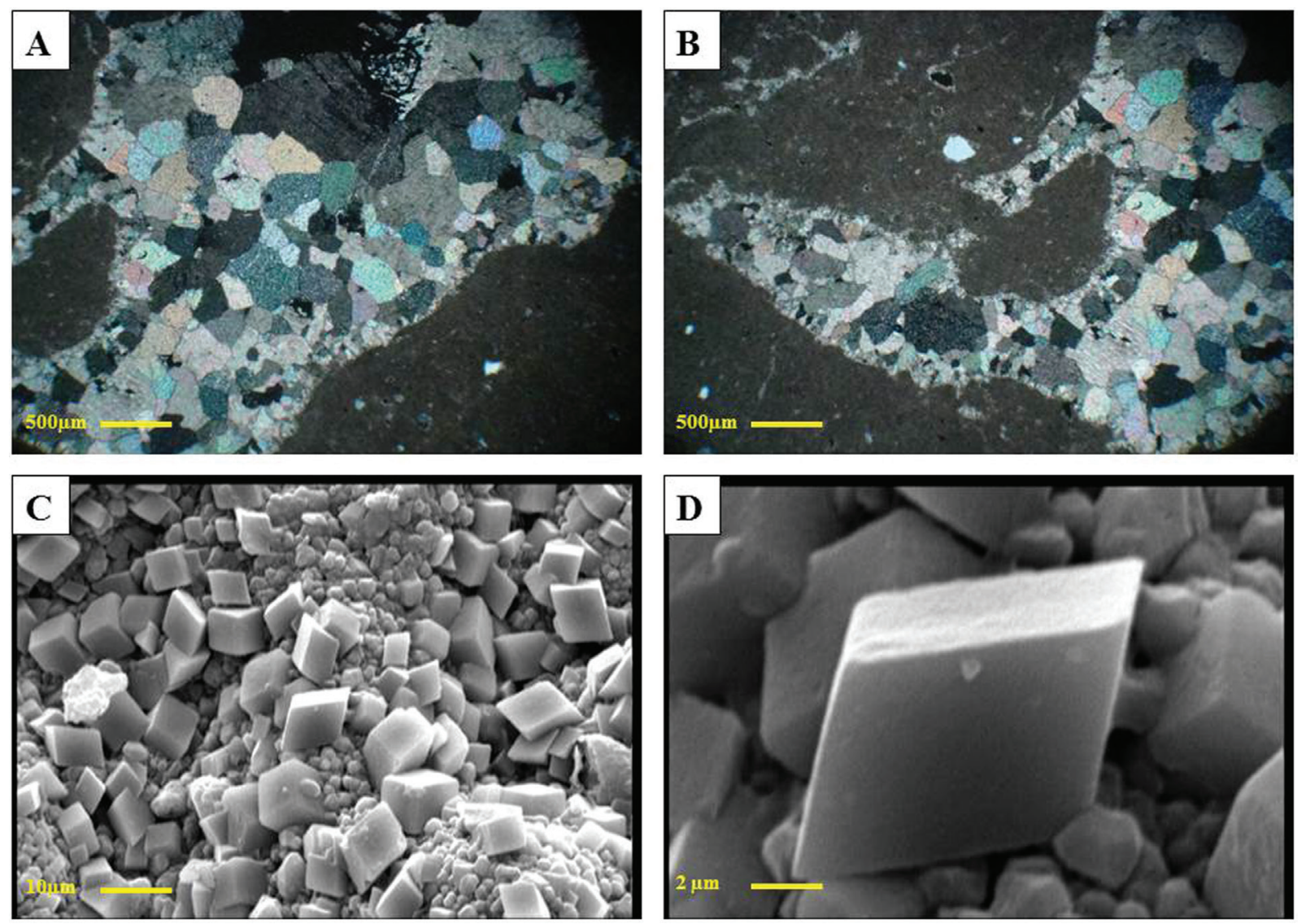

Figure 5. A,B) Photomicrographs of massive travertines in the Qorveh area (crossed nicols). C) SEM image of calcite and dolomite. D) SEM image of rhombohedral-shaped dolomite and calcite. 

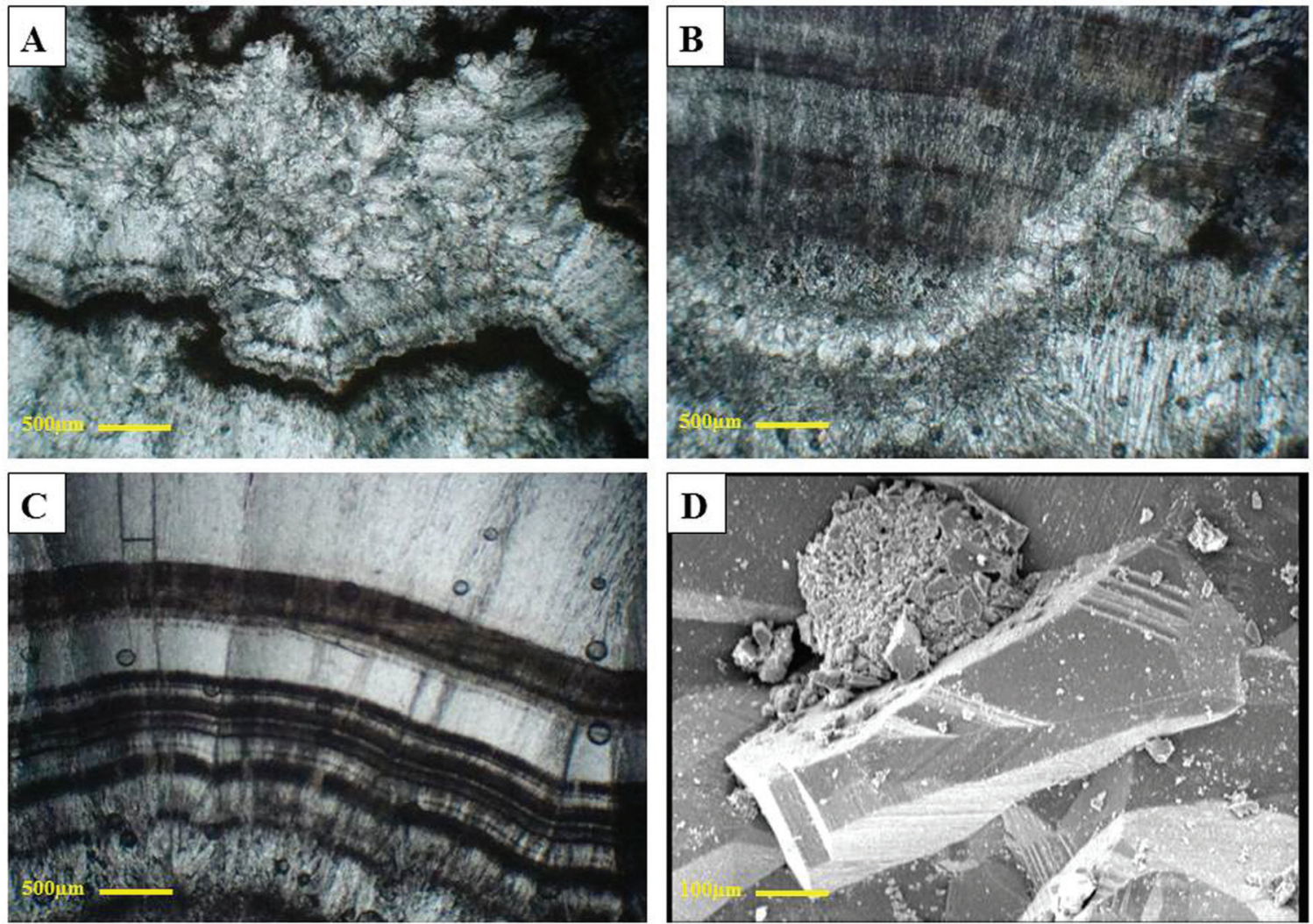

Figure 6. A) Photomicrograph of iron oxides with calcite crystals in the form of light and dark layers (crossed nicols). B) Secondary calcite in fracture and alternation of sparry calcite layers with micrite (crossed nicols). C) Alternation of light and dark layers of calcite and iron oxides (crossed nicols). D) SEM image of layered travertine (blocky calcite).
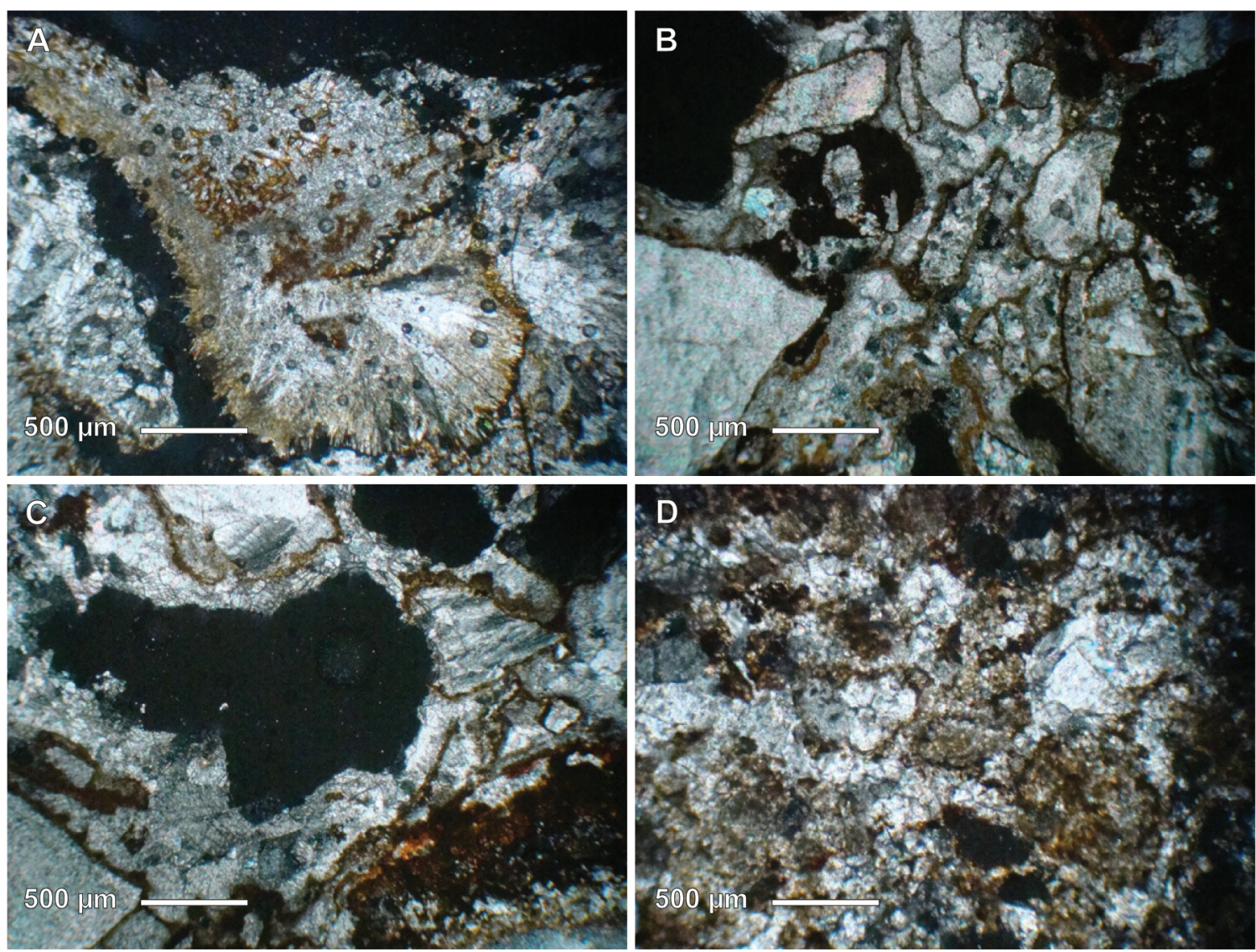

Figure 7. Thin-section images of travertine under a petrological microscope with crossed nicols. Photomicrograph of A) iron oxides coating the surface of calcite crystals, B) coarse anhedral calcite crystals, C) iron oxides around the calcite crystals and D) patchy iron oxide accumulation surrounded by calcite crystals. 

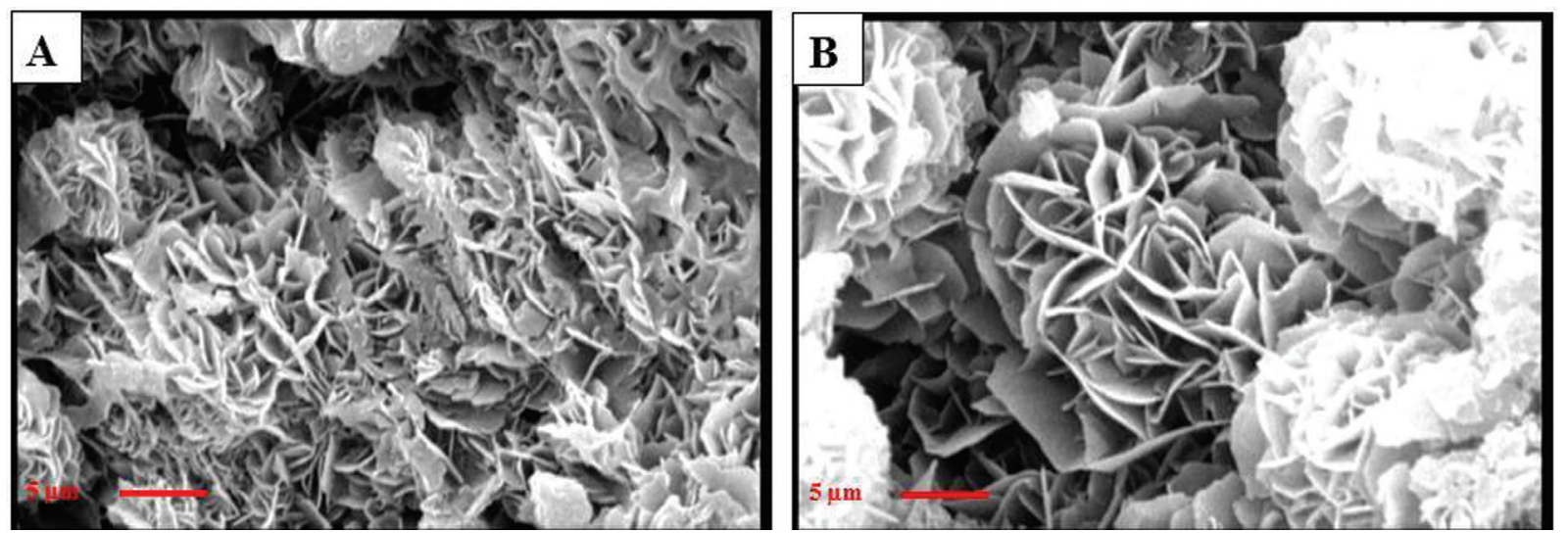

Figure 8. A,B) SEM images of iron-rich spring deposit (iron oxides with cauliflower texture, possibly goethite).
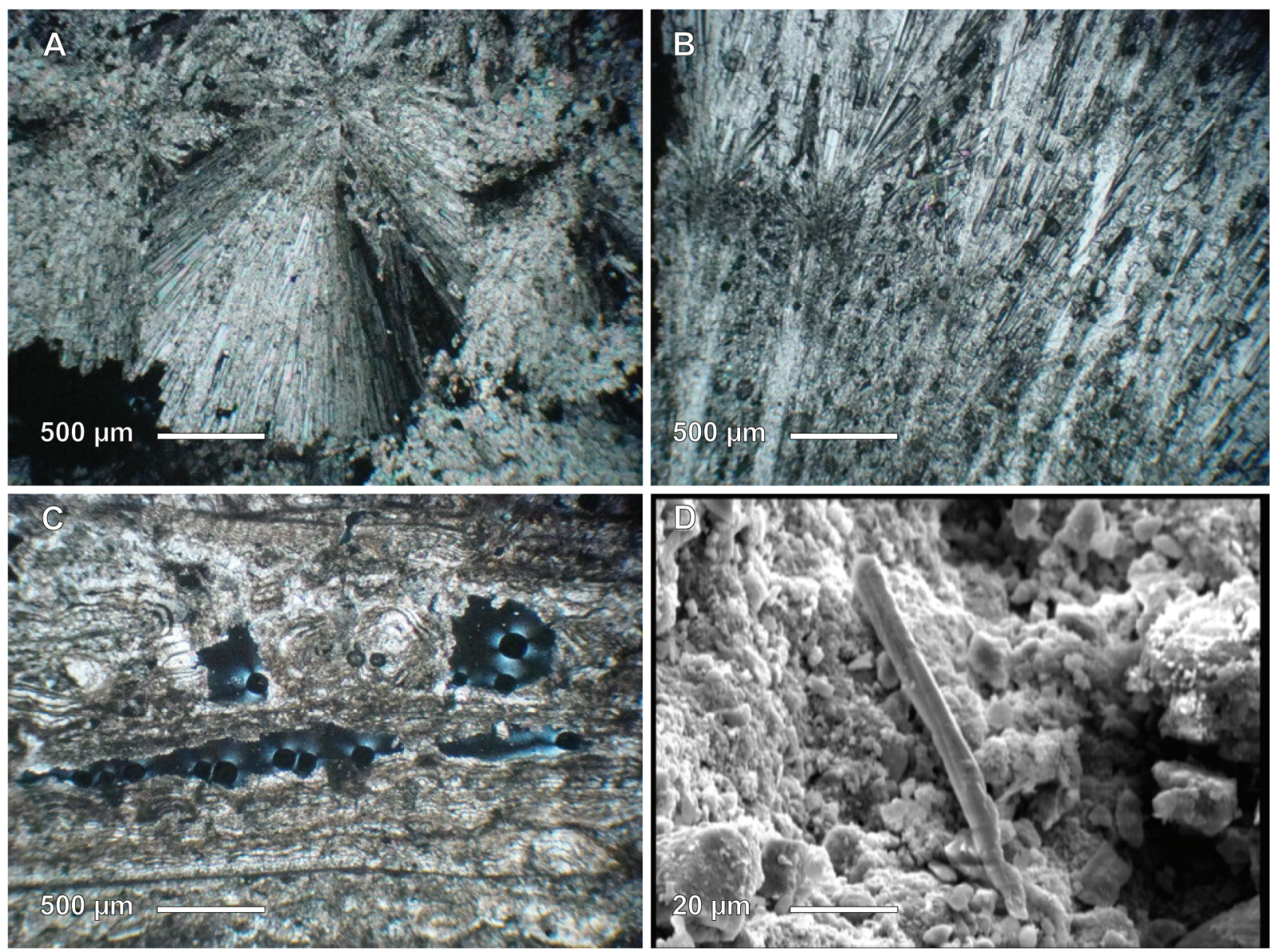

Figure 9. A, B, C) Thin-section image of travertine under a petrological microscope with crossed polars. A) Aragonite crystals of fan-shaped cluster texture, B) aragonite needles, C) alternation of micrite and microspar and D) close-up SEM image of aragonite-bearing travertine with a needle shaped aragonite crystal in the centre.

\section{Discussion}

The regional tectonic setting of Kurdistan and West Azerbaijan provinces shows that this region is tectonically active (Ghasemi and Talbot, 2006). The carbon isotope values of the Qorveh-Takab belt are positive, similar to travertines deposited from thermal systems elsewhere, e.g., in the Andean lake basin (Valero-Garces et al., 2001) and in hot spring carbonates from several locations (Minissale, 2004; Yoshimura et al., 2004; Pentecost, 2005; Anzalone et al., 2007; Rainey and Jones, 2009; Kele et al., 2011).

\begin{tabular}{llcccc} 
Sample Location & $\begin{array}{l}\boldsymbol{\delta}^{13} \mathbf{C}_{\text {(Travertine) }} \\
\text { \%o }\end{array}$ & $\begin{array}{l}\boldsymbol{\delta}^{18} \mathbf{O}_{\text {(PDB) }} \\
\text { \%o }\end{array}$ & $\begin{array}{l}\boldsymbol{\delta}^{18} \mathbf{O}_{\text {(SMow) }} \\
\text { \%o }\end{array}$ & $\begin{array}{l}\boldsymbol{\delta}^{13} \mathbf{C}^{\mathbf{C}} \\
\text { \%o }\end{array}$ \\
\hline T-1 & Qorveh & 8.92 & -2.12 & 28.67 & 0.204 \\
T-3 & Qorveh & 7.59 & -0.68 & 30.16 & -1.392 \\
T-4 & Bijar & 6.41 & -3.07 & 27.70 & -2.808 \\
T-6 & Bijar & 6.08 & -5 & 25.71 & -3.204 \\
T-7 & Takab & 9.72 & -6.94 & 23.71 & 1.164 \\
T-8 & Takab & 8.59 & -8.76 & 21.83 & -0.192 \\
T-9 & Takab & 6.19 & -11.91 & 18.58 & -3.072 \\
T-10 & Takab & 9.84 & -6.53 & 24.13 & 1.308
\end{tabular}

Table 2: Oxygen and carbon isotope composition of the studied samples. 
Thus, there is a significant similarity between the isotopic values of the studied travertines and those of the thermogene travertines. Moreover, $\mathrm{CO}_{2}$ of thermal origin was found in water arising from beneath the Earth's crust (Pentecost, 2005). It is generally accepted that hot springs of magmatic origin are characterized by relatively heavy (=positive) carbon isotopic composition (e.g. Pentecost, 2005; Jones and Renaut, 2010). Furthermore, thermogene travertine is usually massive and is essentially found in regions with recent volcanic or high tectonic activity (Pentecost, 2005). Cenozoic up to Quaternary tectonic movements are reported from the Qorveh-Takab region. Travertines of the study area belong to recent thermal springs and were collected near the active springs.

Therefore, it can be presumed that the source of travertine-depositing springs of the study area is mainly magmatic. The distribution of $\delta^{13} \mathrm{C}$ (VPDB, \%o) of 108 thermogene travertines from different regions of the world (Fig. 10, after Pentecost, 2005) compared to the average of $\delta^{13} \mathrm{C}$ in the study area (+7.9\%o) shows rather high enrichment of the travertines in ${ }^{13} \mathrm{C}$.

\subsection{Source of $\mathrm{CO}_{2}$}

Isotope data can be used to identify the source of carbon dioxide in travertines. To be able to do so, $\delta^{13} \mathrm{C}$ of the $\mathrm{CO}_{2}$ must be calculated. In order to determine the $\delta^{13} \mathrm{C}$ of $\mathrm{CO}_{2}$, we used the following equation (Panichi and Tongiorgi, 1976; Kele et al., 2011):

$$
\delta^{13} \mathrm{C}\left(\mathrm{CO}_{2}\right)=1.2 \delta^{13} \mathrm{C}_{\text {(Travertine) }}-10.5
$$

According to Equation (1), the $\delta^{13} \mathrm{C}$ of the $\mathrm{CO}_{2}$ released from the water during travertine sedimentation can be calculated by measuring the travertine $\delta^{13} \mathrm{C}$ values (Kele et al. 2003; Minissale, 2004). Based on the results obtained from the above-mentioned equation, values of $\delta^{13} \mathrm{C}\left(\mathrm{CO}_{2}\right)$ in the study area are in the range of $-3.2 \%$ o to $+1.3 \%$, with an average value of $0.9 \%$ (Fig. 11).

Actually, the carbon source of thermogene travertines with isotope combination $(-3 \%$ to $+8 \%$ ) is considered to be derived from $\mathrm{CO}_{2}$ originating from limestone decarbonation, mostly with a considerable magmatic component (Pentecost, 2005) and water-rock interaction (dissolution of carbonate).

According to Equation (1), the amount of $\delta^{13} \mathrm{C}$ carbon dioxide released from the water during travertine deposition is determined by measuring the amount of $\delta^{13} \mathrm{C}$ in travertines. In order to determine the origin of $\mathrm{CO}_{2}$, samples of travertines were used that precipitated at a minimum distance from the springs (Kele et al., 2008). In this study, sample (T-6) was used. It was collected exactly at the 'Peer Saleh' spring (Bijar area). According to Hoefs (2004), the source of the $\mathrm{CO}_{2}$ of rocks in the range of $-3 \%$ o to $-7 \%$ o has magmatic origin and is derived from the crust. The value of $\delta^{13} \mathrm{C}\left(\mathrm{CO}_{2}\right)$ of this sample (T-6) is $-3.2 \%$ (Table 2). Consequently, the source of the $\mathrm{CO}_{2}$ in the travertine samples of the study area is magmatic.

Travertines contain high values of ${ }^{13} \mathrm{C}$. Theoretically, these high values could be derived from three sources: The first is thermometamorphic decarbonation. The $\mathrm{CO}_{2}$ released by thermometamorphic decarbonation of carbonate rocks can contribute to the high values of $\delta^{13} \mathrm{C}$ in travertine. The thermogenic origin of $\mathrm{CO}_{2}$ is indicated by the positive values of $\delta^{13} \mathrm{C}$ in some travertines (Uysal et al., 2007). The quick degassing of the dissolved $\mathrm{CO}_{2}$ gas (rich in ${ }^{12} \mathrm{C}$ ), the second factor, during seismic strain cycles, may represent the non-equilibrium

Figure 11. $\delta^{13} \mathrm{C}_{\text {of }} \mathrm{CO}_{2}$ vs. $\delta^{13} \mathrm{C}$ in travertines. 
fractionation and therefore the positive values of $\delta^{13} \mathrm{C}$ of the rest of the gas (Uysal et al., 2009). Photosynthetic activity of microorganisms like algae around the springs may be the third factor responsible for the observed high carbon isotope values (about 9\%o). The presence of algae and other microorganisms is verified by SEM

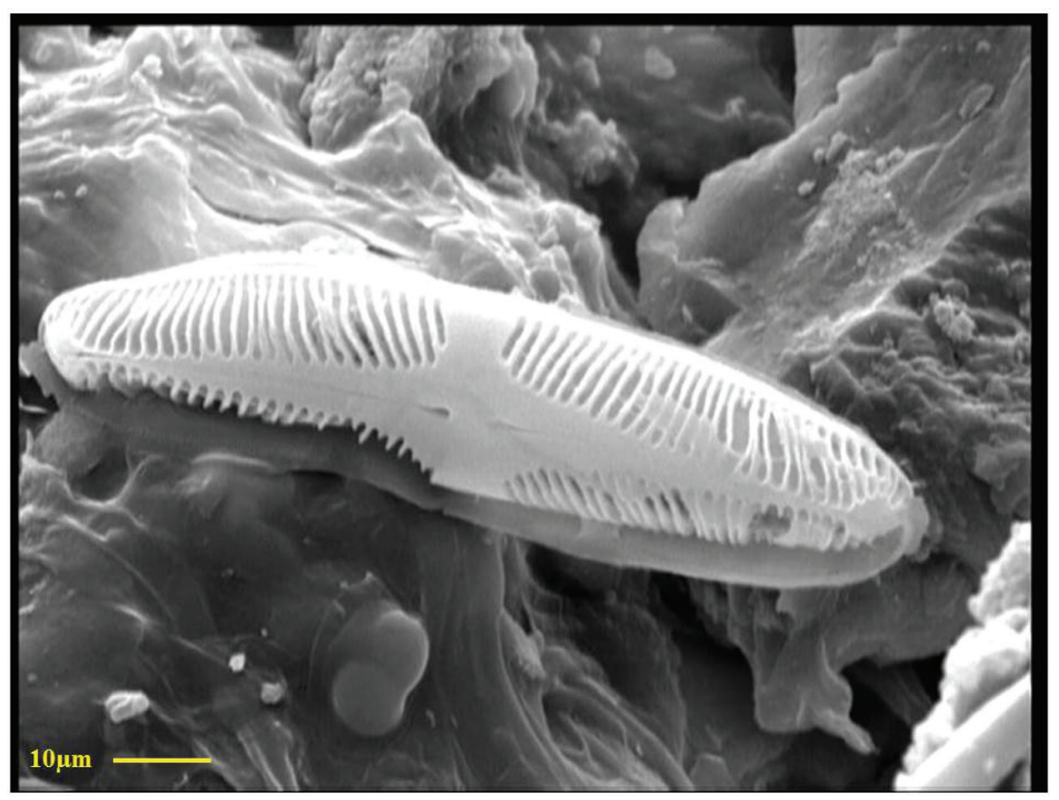

Figure 12. SEM image of Takab travertine (presence of microorganism such as diatom).

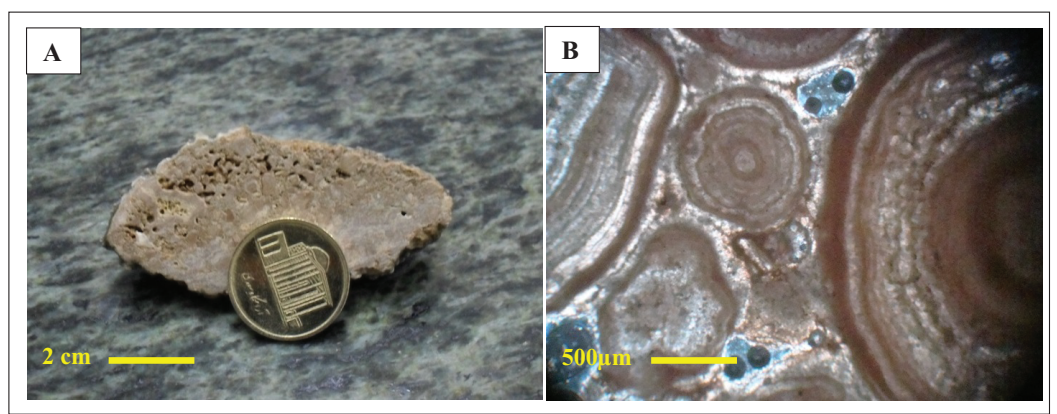

Figure 13. A) Oncoid-bearing sample and B) photomicrograph of oncoids in the study area.

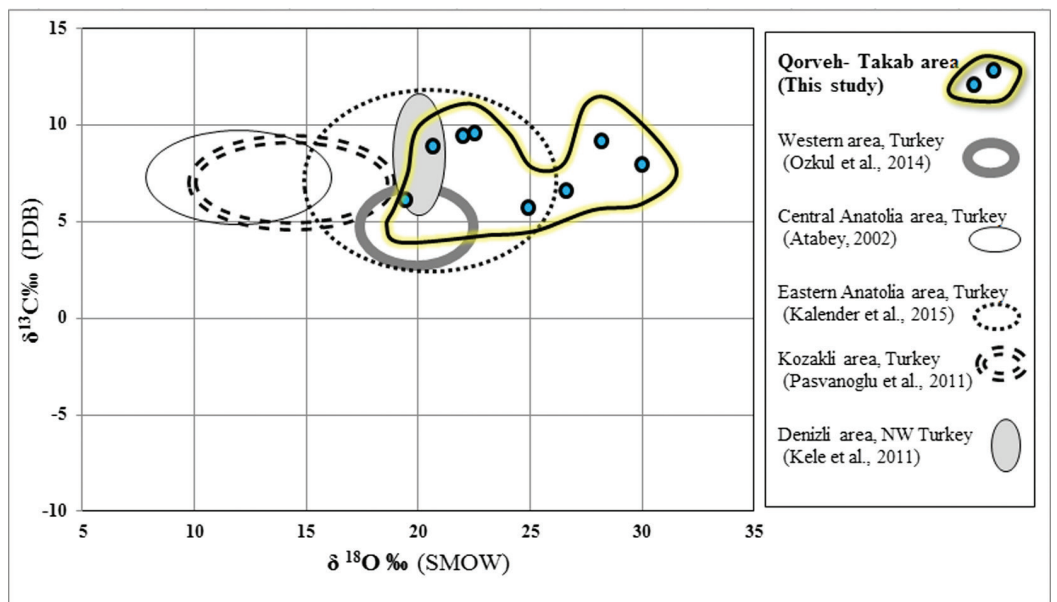

Figure 14. Geochemical comparison of travertine in the Qorveh-Takab area (NW Iran) with travertines from different locations in Turkey. in the studied samples and thus seems to support the latter idea (Fig. 12).

Traces of microbial activity, such as oncoids, can be observed in thin sections from these travertines. By referring to the colonizing algae, many aspects of fluviatile oncoids can be primarily described. Occurring in the streams of a moderate gradient, the oncoids are overturned by occasional flooding (Fig. 13). The oncoid stratum is usually seasonally laminated. It usually includes also radial fibrous calcite, with most of the growth occurring during the warmer months as shown by Pentecost (2005).

\subsection{Isotopic comparison of the traver- tines studied with those in Turkey}

$\delta^{18} \mathrm{O}$ isotope values of samples (Table 2) were calculated based on SMOW (Vienna Standard Mean Ocean Water) standard, by using the following equation (Pentecost, 2005):

$$
\delta^{18} \mathrm{O}_{(\mathrm{SMOW})}=1.0309 \delta^{18} \mathrm{O}_{(\mathrm{VPDB})}+30.92
$$

$\delta^{18} \mathrm{O}(\mathrm{SMOW})$ values of Qorveh, Bijar and Takab travertines range between $+18.5 \%$ o and $+30.1 \%$ (with an average value of $+25.0 \%$ o). The stable isotope composition of the Qorveh-Takab road travertine was compared with main travertine deposits from Turkey that plot at a relatively small distance from each other (Fig. 14). These Turkish travertine deposits also belong to the thermogene travertine category (Atabey, 2002; Kele et al., 2011; Pasvanoglu and Chandrasekharam., 2011; Ozkul et al., 2014; Kalender et al., 2015). According to geological observations and isotopic analysis of the present study, the Kurdistan and West Azerbaijan travertines can be regarded as thermogene travertines and are comparable with those in the Aksaz area in the Uşak province (NW Turkey), Denizli basin (NW Turkey) and travertines from eastern Anatolia.

$\delta^{13} \mathrm{C}$ values of travertines in both regions are high due to decarbonation of limestone, algae activity and rapid degassing. Therefore, it seems that deposition and genesis of travertines in Western Iran and Turkey are quite similar.

\section{Conclusion}

In this study, travertines from Qorveh, Bijar and Takab areas, in the NW of Iran, were investigated using mineralogical and isotope geochemical methods. The travertines investigated were classified as 
a thermogene group, and the source of $\mathrm{CO}_{2}$ in travertine-depositing spring water was determined as crustal magmatic type by analysing ${ }^{18} \mathrm{O}$ and ${ }^{13} \mathrm{C}$ isotopes. Using the measured $\delta^{13} \mathrm{C}$ values of travertines gave the $\delta^{13} \mathrm{C}$ of the $\mathrm{CO}_{2}$ released from the water during travertine deposition (average -0.9\%o). All this reinforce the idea of the Qorveh, Bijar and Takab travertines being, indeed, typical thermogene travertines, closely related to the coeval volcanic activity. According to geological observations and isotopic analysis, the travertines of the present study are largely similar to those of the Denizli Basin and east Anatolia in Turkey.

Based on petrographic studies, the Qorveh-Takab road travertines can be divided into two groups of lithofacies: (1) the pebbly travertine group and (2) the crystalline crust group. $\delta^{18} \mathrm{O}_{\text {(SMOw) }}$ values range from $+18.5 \%$ to $+30.1 \%$, and $\delta^{13} \mathrm{C}_{(\mathrm{VPDB})}$ values range from $+6.08 \%$ to $+9.84 \%$. There is a significant enrichment in $\delta^{13} \mathrm{C}$ values of all travertine types, probably caused by the decarbonation of limestone and also by algal activity and rapid degassing. The morphology of travertines in the study area includes fissure ridges, mounds and fluvial crusts with oncoids. Qorveh-Takab travertines were classified into four groups on the basis of petrographic and SEM images. These travertines include massive, laminated, iron-rich spring deposits and aragonite-bearing classes.

\section{References}

Anzalone, E., Ferreri, V., Sprovieri, M., D’Argenio, B.D., 2007. Travertines as hydrologic archives: the case of the Pontecagnano deposits (southern Italy). Advances in Water Resources, 30, 2159-2175. https://doi.org/10.1016/j. advwatres.2006.09.008

Atabey, E., 2002. The formation of fissure-ridge type laminated travertine-tufa deposits microscopical characteristics and diagenesis, Kirşehir central Anatolia. Bulletin of The Mineral Research and Exploration, 123-124, 59-65.

Boni, M., Gilg, H.A., Balassone, G., Schneider, J., Allen, R.C., Moore, F., 2007. Hypogene Zn carbonate ores in the Angouran deposit, NW Iran. Mineralia Deposita, 42, 799-820. https://doi.org/10.1007/s00126-007-0144-4

Burman, J., Gustafsson, O., Segl, M., Schmitz B., 2005. A simplified method of preparing phosphoric acid for stable isotope analyses of carbonates. Rapid Communications in Mass Spectrometry, 19, 3086-3088. https:// doi.org/10.1002/rcm.2159

Casanova, J., 1986. Les stromatolites continentaux: paleoecologie, paleohydrologie, paleoclimatologie. Application au rift Gregory. Doctoral Thesis. Universite' d'Aix Marseille. France, 70 pp.

Chafetz, H.S. and Folk, R.L., 1984. Travertines: depositional morphology and the bacterially constructed constituents. Journal of Sedimentary Petrology, 54, 289-316.

Chafetz, H.S. and Lawrence, J.R., 1994. Stable isotopic variability within modern travertines. Geographie physique et Quaternaries, 48, 257-273.

D'Argenio, B. and Ferreri,V. 1992. Ambienti di deposizione e litofacies dei travertine quaternari dell'Italia centro-meridionale. Memorie della Società geologica Italiana, 41,861-868.

Gandin, A. and Capezzuoli, E., 2014. Travertine: Distinctive depositional fabrics of carbonates from thermal spring systems. Journal of Sedimentology, 61, 264-290. https://doi.org/10.1111/sed.12087

Ghasemi, A. and Talbot, C.J., 2006. A new scenario for the Sanandaj-Sirjan zone (Iran). Journal of Asian Earth Sciences, 26, 683-693. https://doi.org/10.1016/j. jseaes.2005.01.003

GSI (Geological Survey of Iran), 1999. Geology maps of Ghorveh and Kabudar Press, Ahang regions, western Iran: a digitized final map at 1:100,000 scale, Teheran.

Guo, L.I. and Riding, R., 1998. Hot-Spring Travertine Facies and Sequences, late Pleistocene, Rapolano Terme, Italy. Journal of Sedimentology, 45, 163-180.

Hoefs, J., 2004. Stable Isotope Geochemistry. 5th Edition. Berlin, Germany: Springer-Verlag. 244 pp.

Inskeep, W.P. and McDermott, T.R., 2005. Geothermal Biology and Geochemistry in Yellowstone National Park. Eds., Bozeman MT, USA: Montana State University Publications.

Jones, B. and Renaut, R.W., 2010. Calcareous spring deposits in continental settings. In: Alonso-Zarza, A.M., Tanner, L.H. (Eds), Carbonates in Continental Settings. Facies Environments and Processes, Elsevier, Amsterdam, pp. 177-224.

Kalender, L., Oztekin-Okan, O., İnceoz, M., Çetindağ, B., Yildirim, V., 2015. Geochemistry of travertine deposits in the Eastern Anatolia District: an example of the Karakoçan-Yoğunağaç (Elazığ) and Mazgirt-Dedebağ (Tunceli) travertines, Turkey. Turkish Journal of Earth Sciences, 24, 607-626. https://doi.org/10.3906/yer-1504-27

Karimi Nezhad, M.T., Ghahroudi Tali, M., Hashemi Mahmoudi, M., Pazira, E., 2010. Spatial variability of Sc and $\mathrm{Cd}$ concentrations in relation to land use, parent material and soil properties in topsoils of Northern Ghorveh, Kurdistan Province, Iran. World Applied Sciences Journal, 11, 1105-1113.

Kele, S., Demény, A., Siklósy, Z., Németh, T., Tóth, M., Kovács, M.B., 2008. Chemical and stable isotope compositions of recent hot-water travertines and associated thermal waters, from Egerszalók, Hungary: depositional facies and non-equilibrium fractionations. Sedimentary Geology, 211, 53-72. https://doi.org/10.1016/j. sedgeo.2008.08.004

Kele, S., Ozkul, M., Forizs, I., Gokgoz, A., Baykara, M.O., Alcicek, M.C., Nemeth, T., 2011. Stable isotope geochemical study of Pamukkale travertines: new evidences of low temperature non-equilibrium calcite-water fractionation. Sedimentary Geology, 238, 191-212. https:// doi.org/10.1016/j.sedgeo.2011.04.015

Kele, S., Vaselli, O., Szabo, C., Minissale, A. 2003. Stable isotope geochemistry of Pleistocene travertine from Budakalász (Buda Mts, Hungary). Acta Geologica Hungarica, 46, 161-175.

Keshavarzi, B., Moore, F., Mosaferi, M., Rahmani, F., 2011. The source of natural arsenic contamination 
in groundwater, west of Iran. Water Quality, Exposure and Health, 3, 135-147. https://doi.org/10.1007/ s12403-011-0051-x

Minissale, A., Kerrich, D., Magro, G., 2002. Structural, hydrological, chemical and climatic parameters affecting the precipitation of travertines in the Quaternary along the Tiber valley, north of Rome. Earth and Planetary Science Letters, 203, 709-728.

Minissale, A., 2004. Origin, transport and discharge of $\mathrm{CO}_{2}$ in central Italy. Earth-Science Reviews, 66, 89-141.

Ozkul, M., Gokgoz, A., Kele, S., Baykara, M.O., Shen, C.C., Chang, Y.W., Kaya, A., Hancer, M., Aratman, C., Akin, T., Oru, Z., 2014. Sedimentological and geochemical characteristics of a fluvial travertine: a case from the eastern Mediterranean region. Sedimentology, 61, 291-318. https://doi.org/10.1111/sed.12095

Ozkul, M., Varol, B., Alçiçek, M., Alçiçek, C., 2002. Depositional environments and petrography of Denizli travertines. Bulletin of the Mineral Research and Exploration Journal, 125, 13-29.

Panichi, C. and Tongiorgi, E., 1976. Carbon isotopic composition of $\mathrm{CO}_{2}$ from springs, fumaroles, mofettes and travertines of Central and Southern Italy: a preliminary prospection method of geothermal area. Proceedings of the 2nd U.N. Symposium on Development and Use of Geothermal Resources, 1975: San Francisco, 815-825. Pasvanoglu, S. and Chandrasekharam, D., 2011. Hydrogeochemical and isotopic study of thermal and mineralized waters from the Nevsehir (Kozakli) area, Central Turkey. Journal of Volcanology and Geothermal Research, 202, 241-250. https://doi.org/10.1016/j. jvolgeores.2011.03.003

Pentecost, A., 1995. Geochemistry of carbon dioxide in six travertine-depositing waters of Italy. Journal of Hydrology, 167, 263-278.

Pentecost, A., 2005. Travertine. Springer, London, 443 pp.

Pentecost, A. and Viles, H.A, 1994. A review and reassessment of travertine classification. Geographie physique et Quaternaire, 48, 305-314.

Prado-Perez, A.J., Hueras, A.D., Crespo, M.T., Martin Sanchez, A., Perez Del Villar, L., 2013. Late Pleistocene and Holocene mid-latitude palaeoclimatic and palaeoenvironmental reconstruction: an approach based on the isotopic record from a travertine formation in the Guadix-Baza basin, Spain. Geological Magazine, 150, 1- 24. https://doi.org/10.1017/S0016756812000726

Rahmani Javanmard, S., Tutti, F., Omidian, S., Ranjbaran, M., 2012. Mineralogy and stable isotope geochemistry of the Ab Ask travertines in Damavand geothermal field, Northeast Tehran, Iran. Central European Geology, 55, 187-212. https://doi.org/10.1556/CEuGeol.55.2012.2.5

Rainey, D.K. and Jones, B., 2009. Abiotic versus biotic controls on the development of the Fairmont Hot Springs carbonate deposit, British Columbia, Canada. Sedimentology, 56, 1832-1857. https://doi. org/10.1111/j.1365-3091.2009.01059.x

Selim, H.H. and Yanik, G., 2009. Development of the Cambazli (Turgutlu/MANISA) fissure-ridge-type travertine and relationship with active tectonics, Gediz Graben, Turkey. Quaternary International, 199, 57-163. https:// doi.org/10.1016/j.quaint.2008.04.009

Sierralta, M., Kele, S., Melcher, F., Hambach, U., Reinders, J., Van Geldern, R., Frechen, M., 2010. Uranium series dating of travertine from Sutto: Implications for reconstruction of environmental change in Hungary. Quaternary International, 222, 178-193. https://doi.org/10.1016/j. quaint.2009.04.004

Uysal, I.T., Feng, Y., Zhao, J., Altunel, E., Weatherley, D., Karabacak, V., Cengiz, O., Golding, S.D., Lawrence, M.G., Collerson, K.D., 2007. U-Series dating and geochemical tracing of late Quaternary travertine in coseismic fissures. Earth and Planetary Science Letters, 257, 450462. https://doi.org/10.1016/j.epsl.2007.03.004

Uysal, T., Feng, Y., Zhao, J., Isik, V., Nuriel, P., Golding, S.D., 2009. Hydrothermal $\mathrm{CO}_{2}$ degassing in seismically active zones during the late Quaternary. Chemical Geology, 265, 442-454. https://doi.org/10.1016/j. chemgeo.2009.05.011

Valero-Garces, B.L., Arenas, C., Delgado-Huertas, A. 2001. Depositional environments of Quaternary lacustrine travertines and stromatolites from high-altitude Andean lakes, northwestern Argentina. Canadian Journal of Earth Sciences, 38, 1263-1283.

Viles, H.A. and Pentecost, A., 2007. Tufa and travertine. In: Nash, D.J., McLaren, S.J. (Eds.). Geochemical Sediments and Landscapes. Wiley-Blackwell, Oxford, pp. 173-199.

Viles, H.A. and Goudie, A.S., 1990. Tufas, travertines and allied carbonate deposits. Progress in Physical Geography, 14, 19-41.

Wang, H., Yan, H., Liu, Z., 2014. Contrasts in variations of the carbon and oxygen isotopic composition of travertines formed in pools and a ramp stream at Huanglong Ravine, China: Implications for paleoclimatic interpretations. Geochimica et Cosmochimica Acta, 125, 34-48. https://doi.org/10.1016/j.gca.2013.10.001

Yoshimura, K., Liu, Z., Cao, J., Yuan, D., Inokura, Y., Noto, M., 2004. Deep source $\mathrm{CO}_{2}$ in natural waters and its role in extensive tufa deposition in the Huanglong Ravines, Sichuan, China. Chemical Geology, 205, 141-153. https:// doi.org/10.1016/j.chemgeo.2004.01.004

Received: 15052017

Accepted: 18012018

Reihaneh ROSHANAK ${ }^{1 *}{ }^{*}$, Farid MOORE ${ }^{21}$, Alireza ZARASVANDI ${ }^{1)}$, Behnam KESHAVARZI' ${ }^{2)}$ \& Reinhard GRATZER ${ }^{3)}$

1) Department of Geology, Faculty of Sciences, Shahid Chamran University, Ahvaz 87234, Iran;

2) Department of Earth Sciences, College of Sciences, Shiraz University, Shiraz 71454, Iran;

3) Department of Applied Geosciences and Geophysics, Montanuniversitaet Leoben, Peter-Tunner-Strasse 5, 8700 Leoben, Austria;

*) Corresponding author, r-roshanak@phdstu.scu.ac.ir 